This item was submitted to Loughborough's Research Repository by the author.

Items in Figshare are protected by copyright, with all rights reserved, unless otherwise indicated.

\title{
Uncovering ecodesign dilemmas: A path to business model innovation
}

PLEASE CITE THE PUBLISHED VERSION

http://dx.doi.org/10.1016/j.jclepro.2016.11.095

\section{PUBLISHER}

(c) Elsevier

VERSION

AM (Accepted Manuscript)

\section{PUBLISHER STATEMENT}

This work is made available according to the conditions of the Creative Commons Attribution-NonCommercialNoDerivatives 4.0 International (CC BY-NC-ND 4.0) licence. Full details of this licence are available at: https://creativecommons.org/licenses/by-nc-nd/4.0/

\section{LICENCE}

CC BY-NC-ND 4.0

\section{REPOSITORY RECORD}

Prendeville, Sharon, Frank O'Connor, Nancy Bocken, and Conny Bakker. 2016. “Uncovering Ecodesign

Dilemmas: A Path to Business Model Innovation". Loughborough University. https://hdl.handle.net/2134/23434. 


\section{Accepted Manuscript}

Uncovering ecodesign dilemmas: A path to business model innovation

Sharon M. Prendeville, Frank O'Connor, Nancy M.P. Bocken, Conny Bakker

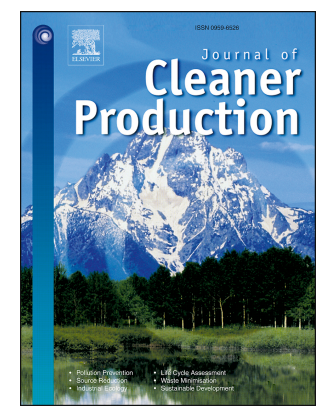

PII: S0959-6526(16)31940-0

DOI: $\quad$ 10.1016/j.jclepro.2016.11.095

Reference: JCLP 8484

To appear in: Journal of Cleaner Production

Received Date: 1 July 2016

Revised Date: 6 November 2016

Accepted Date: 16 November 2016

Please cite this article as: Prendeville SM, O'Connor F, Bocken NMP, Bakker C, Uncovering ecodesign dilemmas: A path to business model innovation, Journal of Cleaner Production (2016), doi: 10.1016/ j.jclepro.2016.11.095.

This is a PDF file of an unedited manuscript that has been accepted for publication. As a service to our customers we are providing this early version of the manuscript. The manuscript will undergo copyediting, typesetting, and review of the resulting proof before it is published in its final form. Please note that during the production process errors may be discovered which could affect the content, and all legal disclaimers that apply to the journal pertain. 


\section{Uncovering Ecodesign Dilemmas: A Path to Business Model Innovation}

*Sharon M. Prendevilleac, Frank O’Connor ${ }_{b}$, Nancy M.P. Bocken, Conny Bakker ${ }_{c}$

${ }_{a}$ Loughborough University London, 3 Lesney Avenue, The Broadcast Centre, Here East Queen Elizabeth Olympic Park, London, E15 2GZ, United Kingdom

${ }_{b}$ Ecodesign Centre, Llandaff, 200 Western Avenue, Cardiff Metropolitan University, Cardiff, CF5 2YB, Wales

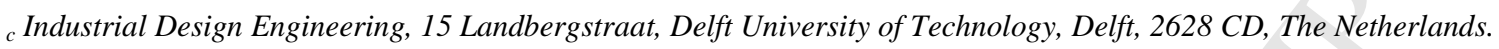

*Corresponding author: E-mail: s.prendeville@lboro.ac.uk; Telephone: +44 (0) 7707484478 
Word Count: 7631 including tables excluding references and appendices

*Sharon M. Prendeville ${ }_{a, b}$, Frank O'Connor, , Nancy M.P. Bocken ${ }_{b}$, Conny Bakker a Loughborough University London, 3 Lesney Avenue, The Broadcast Centre, Here East Queen Elizabeth Olympic Park, London, E15 2GZ, United Kingdom ${ }_{b}$ Industrial Design Engineering, 15 Landbergstraat, Delft University of Technology, Delft, The Netherlands. ${ }_{c}$ Ecodesign Centre, Wales

*Corresponding author: E-mail: s.prendeville@lboro.ac.uk; Telephone: 0044 (0) 7707484478

Keywords: Ecodesign, Ecodesign Maturity, Dilemmas, Trade-Offs, Business Model Innovation

\section{Introduction}

Ecodesign is a collaborative, proactive and systematic design and management process that considers the full life-cycle environmental impacts of packaging, products, processes, services, organisations and systems (Sherwin \& Evans, 2000; O'Rafferty \& O'Connor, 2010, Pigosso et al., 2013; Dekoninck et al., 2016). It is a product life-cycle management approach to mitigate uncoordinated product planning, for example, eliminating a toxic substance should not lead to higher energy consumption, which on balance could have a negative impact on the environment (European Commission, 2012). The core premise of an ecodesign approach is the need to foster life cycle thinking through design, to consider the entire product life cycle (Bonou et al., 2016) in collaboration with stakeholders (O'Connor \& Hawkes, 2001; Tyl et al., 2015). Implementation of such principles are essential if industry is to become more sustainable in the long-term. Yet, it is broadly accepted that many companies still fall short of integrating ecodesign in day-to-day design practices (Pigosso et al., 2013; Bonou et al., 2016; Dekoninck et al., 2016).

In recent years, ecodesign researchers call for a move away from further tool-development, to focus more on processes and methods to integrate ecodesign strategy within project management processes and wider company goals, as a means for effective ecodesign implementation (Pigosso 
et al, 2013; Domingo et al., 2015; Verhulst \& Boks, 2012). In the context of this paper, ecodesign dilemmas are defined as scenarios that either pose upfront challenges to the decisionmaker, or later lead to one or more unexpected or contradictory outcomes of ecodesign decisionmaking. In the past, such dilemmas, have been described as 'trade-offs' and are most often approached in the literature from a positivist viewpoint, with an emphasis on measurement and the need to compare product characteristics at a product performance level (Brezet \& van Hemel, 1997). Despite previous research showing that technical tools fall short of supporting practitioners with handling trade-offs (Byggeth \& Hochschorner, 2006) today this emphasis on technical solutions prevails (Niekamp et al., 2015; Bocken et al., 2011; Russo et al., 2011, 2014, 2016).

The aim of this article is to explore ecodesign dilemmas from a constructivist viewpoint: How do ecodesign dilemmas relate to a firm's ecodesign evolution? Constructivist, meaning, that reality is constructed through the lived experiences of individuals (Knutsen \& Moses, 2007). Therefore, this article takes a pragmatic approach, focusing on the practitioner's reality of negotiating ecodesign dilemmas. In light of this, the research was undertaken at a single firm, a UK-based design-led office furniture manufacturer. The research methodology is an action-led immersive case-study, based on four in-depth case studies of new product development (NPD). Through the analysis we identify the firm's main learning phases and define a unique set of ecodesign dilemmas. These are categorised as: tensions; hierarchies; contradictions; and oversights. We describe how these dilemmas were navigated in practice and the lessons learned internalised by the firm. From this a new framework linking ecodesign dilemmas, ecodesign strategy and business strategy is developed. The research illustrates how ecodesign dilemmas fuel cycles of learning ultimately stimulating innovation in the wider business model towards a new leasing approach.

The remainder of the article includes a literature review focused on recent developments in the field of ecodesign, ecodesign in office furniture and ecodesign dilemmas. This is followed by a description of the case study research method. The results section describes the firm's design approach, key decisions made during each NPD and the ecodesign dilemmas identified for each case. The analysis and discussion include a cross-case analysis of all of the dilemmas identified 
and a reflection on the firm's trajectory of ecodesign decision-making over the course of nine years. Finally, the research limitations and conclusions are discussed.

\section{Literature}

This section reviews the literature on ecodesign in its contemporary context and introduces the topic of ecodesign dilemmas.

\subsection{Ecodesign - A Contemporary view}

As early as 1993, Fiksel proposed that successful ecodesign requires an integrated management approach to optimise strategic decisions. Recently, the ecodesign literature has focused increasingly on the management perspective of ecodesign. Some empirical findings state that a more 'considered' (Domingo et al., 2015) approach to ecodesign is needed than has been adopted up to now. For instance, management hierarches, environmental knowledge, strategic intentions for a given project and the business drivers for ecodesign are important contextual factors for successful ecodesign integration (Domingo et al., 2015). Indeed, other authors advocate for proactive management intervention through improved project management processes (Brones et al., 2014) change management (Verhulst et al., 2007; Le Pochat; 2007) ecodesign maturity models (Pigosso et al., 2013) and integrated systemic approaches (Brones et al., 2015) that also incorporate the wider business context (Domingo et al., 2015). In essence, strategic company objectives, overarching design strategy and project management processes all need consideration for effective ecodesign implementation (Pigosso et al, 2013; Domingo et al., 2015; Verhulst \& Boks, 2012). This echoes recent developments in wider sustainable innovation literature towards the concept of sustainable business models (Boons et al., 2013; Bocken et al., 2014). A business model describes the actions that make up a company's day-to-day operations (eg ways of selling, routes to market) (Boons et al., 2013; Bocken et al., 2014). One example of a sustainable business model is a product-service-system (PSS), where customers avail of a combination of products and services offered by firms, an approach that has the potential to reduce material flows in the economy (Tukker, 2015).

Specifically, Brones et al (2015) derived a theory-driven ecodesign integration framework, outlining the need for vertical (strategic, tactical and operational) as well as transversal (change 
management, cultural and human factors) integration of ecodesign in company processes. Similarly, Zhang et al (2013) propose a 'navigation framework' that also integrates this operational, tactical and strategic approach. Gmelin and Seuring (2014) propose a theoretical conceptual framework outlining the interrelations between sustainability and project management, highlighting collaboration as a critical linking factor between key components of a sustainable NPD. Pigosso et al (2013) propose that companies need roadmaps to guide ecodesign maturity and outline the broad stages of ecodesign implementation that firms can undergo, through a theory-driven model, underpinned by five evolution levels of ecodesign maturity. Nevertheless, Martens and Carvalho (2016) conclude, from multiple case-studies, that while firms are concerned with sustainability in project management, there still remains a knowledgeaction gap and they identify that integration of sustainability, during product development, is still not happening. This paper proposes that ecodesign dilemmas, when properly managed, can contribute to the holistic (strategic, tactical, operational) integration of ecodesign in firms.

\subsection{Ecodesign in Office Furniture}

The key environmental impacts of office chairs occur during raw material, extraction, production and end-of-life stages (Collado-Ruiz et al. 2013; Joint Research Council, 2013). Studies on office furniture and the environment range from industrial Life Cycle Assessment (LCA) case studies (Spitzley et al., 2006; Gamage et al., 2007) to business-oriented accounts of the practicalities of adopting cradle-to-cradle design (Lee \& Bony, 2008). For example, Spitzley et al., (2006) assess a marketed product, by the company Steelcase, from cradle-to-grave, identifying the replacement of virgin material with recyclate as a key design strategy to reduce this products' environmental impact. Similarly, Gamage et al, (2007) assess two variations of a Formway task chair, one with an aluminium base and an alternative option with a nylon base. The study finds the aluminium option to have greatest environmental impacts and recommends designing for recyclability to address this [ibid]. In summary, these studies make recommendations on specific ecodesign 'guidelines': heuristics that provide good practice principles to design practitioners (Knight \& Jenkins, 2009). Other studies on ecodesign in office furniture include broad recommendations on design guidelines from 'design for durability' to 'design for recyclability' (Besch, 2005; Carlos et al., 2008; Borchardt et al., 2012). During the action research stages of this study, the design 
practitioners at the firm were observed to focus on a similar set of ecodesign strategies and these were used as the basis for mapping ecodesign dilemmas in this work.

\subsection{Ecodesign Dilemmas}

In 2006, Byggeth and Horschoner reviewed 15 ecodesign tools and concluded that none effectively support decision-making in trade-off situations. Furthermore, academics have focused excessively on the development of tools for ecodesign (Baumann, 2002; Bovea \& Pérez-Belis, 2012; Domingo et al, 2015; Pigosso, 2016) yet these are not internalised by industry (Pigosso, 2016) because they diverge from industry needs, are overly complex, or too specific, or indeed companies require bespoke approaches (Rossi et al, 2016).

Despite this awareness of the shortcomings of ecodesign tools, the work on trade-off decisionmaking to-date is still approached in the literature through a largely positivist viewpoint. This means many structured, technical tools are developed. For example, the research focuses on tooloriented perspectives such as TRIZ (Russo et al., 2011; 2014; 2016; Bocken et al., 2011), multicriteria decision-making processes (Niekamp et al., 2015), which can include material selection tools (Al-Oqla, \& Sapuan 2015; Al-Oqla et al., 2014) and analytical hierarchy processes (AHP) (Ramanujan et al., 2012). Similarly, Ashby et al. (2011) developed a semiquantitative engineering-led method to enable optimisation between product characteristics.

Trade-offs are also discussed in the literature in a broad sense, in relation to environmental management (see for example: Gibson, 2005; McShane et al., 2011). Table 1 describes examples of ecodesign dilemmas linked to ecodesign guidelines identified in the literature. Nevertheless, ecodesign dilemmas are still perceived to be an overlooked topic in the literature (De Souza, 2013) and are identified as an important ecodesign research topic requiring further work (Paulson \& Sundin, 2015) to adequately support the needs of industry. This study builds on this existing know-how by offering insight on how ecodesign dilemmas are navigated from a practitioner's perspective. 
Table 1. Examples of Ecodesign Dilemmas

\begin{tabular}{|c|c|c|c|c|}
\hline Ecodesign Dilemmas & Positive Outcomes & Negative Outcomes & $\begin{array}{l}\text { Relevant } \\
\text { Sectors }\end{array}$ & Source \\
\hline $\begin{array}{l}\text { Durability vs Light- } \\
\text { weighting: Greater } \\
\text { durability is achieved } \\
\text { through higher material } \\
\text { use to strengthen parts }\end{array}$ & $\begin{array}{l}\text { Potentially longer } \\
\text { product life through } \\
\text { more durable design } \\
\text { - Light weighting can } \\
\text { improve fuel efficiency }\end{array}$ & $\begin{array}{l}\text { - Higher upfront material } \\
\text { use } \\
\text { - End of life processing of } \\
\text { light weighting materials } \\
\text { perceived problematic }\end{array}$ & $\begin{array}{l}\text { Furniture, } \\
\text { Automotive }\end{array}$ & Brennan et al., (2015) \\
\hline $\begin{array}{l}\text { Life extension } \\
\text { strategies (repair, } \\
\text { remanufacturing) } \\
\text { prolong product } \\
\text { lifetimes, preserving } \\
\text { material resources, yet } \\
\text { new products may be } \\
\text { more energy efficient }\end{array}$ & $\begin{array}{l}\text { - Longer product life } \\
\text { - Positive social outcome } \\
\text { (less waste) }\end{array}$ & $\begin{array}{l}\text { - Higher upfront material } \\
\text { use to support durability } \\
\text { requirements of } \\
\text { repairable goods } \\
\text { - Sometimes more energy } \\
\text { efficient to replace old } \\
\text { goods with new ones }\end{array}$ & $\begin{array}{l}\text { Electrical } \\
\text { Electronic }\end{array}$ & $\begin{array}{l}\text { Gutowski et al. (2011) } \\
\text { Bakker et al., (2012) }\end{array}$ \\
\hline $\begin{array}{l}\text { Light-weighting vs } \\
\text { high use of composite } \\
\text { material }\end{array}$ & $\begin{array}{l}\text { - Reduced material use } \\
\text { - Good fuel efficiency }\end{array}$ & $\begin{array}{l}\text { - Reduced recycling } \\
\text { capabilities }\end{array}$ & Automotive & Brennan et al. (2015) \\
\hline $\begin{array}{l}\text { Recycled content } \\
\text { inclusion shortens } \\
\text { product and/or part } \\
\text { lifetime due to lower } \\
\text { quality }\end{array}$ & $\begin{array}{l}\text { - Material efficiency } \\
\text { - Lower environmental } \\
\text { impact for some } \\
\text { indicators }\end{array}$ & $\begin{array}{l}\text { Durability: early } \\
\text { part/product failure }\end{array}$ & Furniture & $\begin{array}{l}\text { Luttropp \& Laegersted, } \\
2006\end{array}$ \\
\hline
\end{tabular}

\subsection{Research \& Practice Gap}

Companies still grapple with the complexity of integrating sustainability into their design processes (Bonou et al., 2016). Contemporary ecodesign research advocates for more strategic approaches to ecodesign implementation, by integrating ecodesign in management processes and considering wider company objectives. However, many methods discussed are derived from theory (e.g. Pigosso et al., 2013; Verhulst et al., 2007; Brones et al., 2015) with still a lack of insight on ecodesign integration from a practical industrial perspective (Bonou et al., 2016; Brones et al., 2015; Deutz et al, 2013; Pigosso et al., 2016). In addition, in the literature, academics convey how a company can grow through one or more levels of ecodesign maturity that are characterised by certain actions: operational (eg ecodesign tools), tactical (eg management processes), strategic (eg business context, external collaborators). In this study we 
seek to integrate the concept of 'ecodesign dilemmas' within this contemporary view, by exploring how these ecodesign dilemmas impact a firm's ecodesign maturity: How do ecodesign dilemmas relate to a firm's ecodesign evolution? Fig. 1 describes the conceptual framework integrating these topics. It proposes that recognising and dealing with ecodesign dilemmas stimulates cycles of learning and thereby contributes to a firm's evolution towards ecodesign maturity over time.

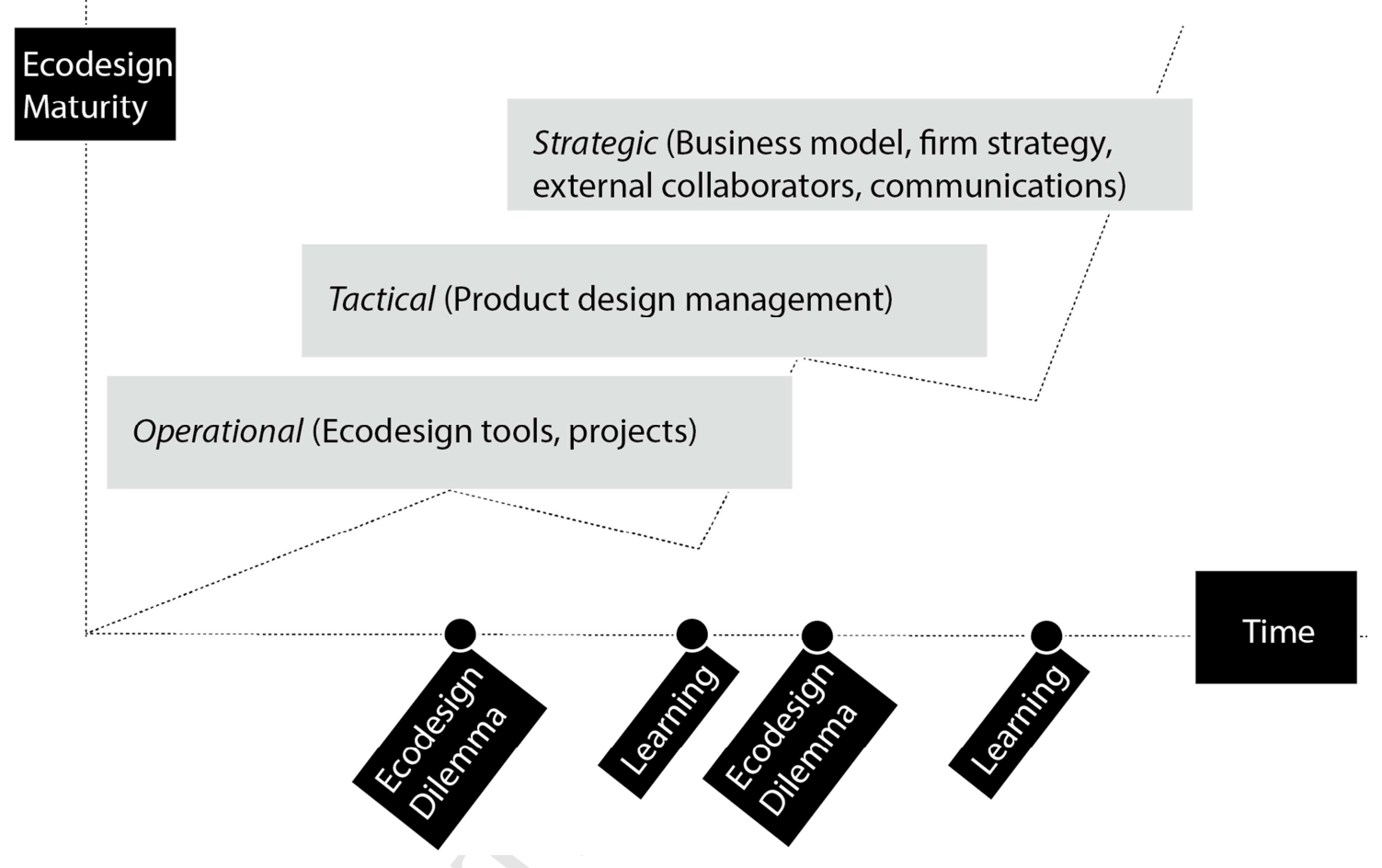

Fig. 1 Conceptual Framework linking Ecodesign Dilemmas with Ecodesign Maturity (Adapted from Brones et al. 2015; Pigosso et al., 2013)

\section{Research Methods}

The study is approached from a social constructivist ontology, which promotes a focus on real world research (Moses \& Knutsen, 2007). The research method is a single in-depth case study of a company in transition and a case study is chosen as an appropriate method because it is wellsuited to build theory from qualitative, context-based data (Yin, 2003). According to Eisenhardt and Graebner (2007) and Yin (2003) single case studies may be chosen if they are revelatory, provide extreme exemplars, or provide particular opportunities for unusual research access. In this research, the single case is illuminating, insofar as it provides an in-depth view of ecodesign 
in practice, when such accounts are rare. Through four embedded case studies of NPD the firm's awareness of ecodesign dilemmas is linked to cycles of operational, tactical and eventually strategic decision-making.

\subsection{An Action Research Approach}

The research was undertaken in collaboration with the design team at the company in a participatory, action-led way involving the use of deliberate, exploratory and collaborative methods over time (Van de Ven, 2007). Action research is a flexible research approach (Van de Ven, 2007) which works well with case studies (Robson 2011). Koshy et al. (2010) state that it is this flexibility that captures the emergent nature of action research, often bringing richness and uniqueness to a study. Bryman and Bell (2005) describe how action research approaches are iterative and focus on changing thinking through collaboration. This perspective was chosen as appropriately sensitive to the company at the outset, to ensure trust and connection with the main participants. The researcher's activities spanned a period of three years, which included conducting environmental evaluations in collaboration with a senior designer and supporting broader environmental initiatives at the firm. The main researcher also participated in management and interval project meetings relating to live NPDs, shadowed designers during supplier visits (as-and-when) and actively participated in potential new supplier meetings.

\subsection{Research Context and Case background}

This paper discusses the case of Orangebox, a company which designs and manufactures contemporary office furniture, focusing on the development of new products for sale into business-to-business markets. The global furniture sector is a mature global market accounting for upwards of $1 \%$ of total manufactured goods (CEPS, 2014). In the UK, the office furniture manufacturing sector generated $£ 2.2 \mathrm{bn}$ in revenues distributed between 910 national firms (IBIS World, 2015). It is a low technology innovation sector [ibid]. In 2006, the EU identified furniture as an important sector for its future integrated product policy actions for reducing the EU's environmental impacts (EIPRO, 2006).

Orangebox was founded in 1998 when a senior designer negotiated a buy-out from, what was then, a Steelcase-owned company and is acting managing director to this day. Over the years 
Orangebox has participated in an Ecodesign Initiative Award (2007) and adopted a C2C certification for an office task chair. This C2C certification is a 'design protocol' (Braungart et al., 2007) developed by Mcdonough Braungart Design Chemistry, which focuses on closing material loops, through recycling, while also evaluating toxicity of materials (with recommendations for improvement options) and advocating solar energy use. The firm implemented these initiatives in the absence of any specific ecodesign regulations that push it towards positive practices. Ecodesign criteria are defined in the design brief at the beginning of the NPD process and this is supported by use of abridged LCA tools. In 2014, the firm initiated a pilot activity to introduce remanufacturing, offered through a new financial leasing contract, into its business model (Costa et al., 2015).

Table 2 summarizes abridged LCA results for the four product case studies presented in this article. The assessments were undertaken using an abridged LCA tool which normalizes results to a single score (millipoints). Generalized data was used where data was unavailable and a bestfit approach was used when selecting data. The results were validated by an LCA specialist at the software company. The full abridged LCA results and methods are reported on in Prendeville (2015). Two sets of carbon foot-printing results are shown in Table 2. The first set of carbon foot-prints were undertaken by the firm, predominantly for communication purposes, using a bespoke tool developed for the UK furniture sector by the Furniture Industry Research Association. The second set are built using the Sustainable Minds abridged LCA tool. A UK study undertaken by FIRA (2011) assessed 13 task chairs and found the average chair to weigh approximately $18-19 \mathrm{~kg}$ with an average carbon footprint of $74 \mathrm{~kg} \mathrm{CO} 2 \mathrm{eq}-$.

Table 2. Summary of Environmental Impacts of Four Cases (Prendeville et al., 2013; 2015; Orangebox, 2015)

\begin{tabular}{llllll}
\hline Weight $(\mathrm{kg})$ & $\begin{array}{l}\text { Recycled } \\
\text { Content }\end{array}$ & $\begin{array}{l}\text { CFP-A } \\
(\text { Kg CO2eq- })\end{array}$ & $\begin{array}{l}\text { CFP-B } \\
(\text { Kg CO2eq- })\end{array}$ & $\begin{array}{l}\text { Abridged LCA Score } \\
(\text { mPTs per 1hr service })\end{array}$ \\
\hline A & 17.2 & 6.9 & 51 & 96 & 0.072 \\
\hline B & 7 & No data. & 31 & No data. & No data. \\
\hline C & 21 & 11 & 63.8 & 130 & 0.48 \\
\hline D & 14.7 & 2.7 & $50^{*}$ & 95 & 0.067 \\
\hline
\end{tabular}

$* C F P=$ Carbon Foot-print, $m P T s=$ millipoints 


\subsection{Case Studies of New Product Development}

Table 3 shows an overview of the case studies of four NPDs. The case studies focus on telling the story of the firm's transition, by describing the ecodesign targets set at the beginning of each project and how this links to the outcomes in the final product. Eisenhardt and Graebner (2007) recommend that case study selection is informed by the topics dictating the research study. These are as follows:

- The product case studies were based on two similar product types, the task and visitor seating portfolios, to foster comparability between products.

- $\quad$ Each NPD was led by a different designer within the design team, to represent a range of views and approaches to decision-making.

- The case studies occurred over a timeframe of nine years, representing a sequence of new chairs brought to market and during which time a number of activities within the business contributed to increasing awareness of sustainability issues (Ecodesign Initiative Award, C2C certification).

- The seating portfolio has been the central focus of the company's ecodesign activity.

A case protocol was used to guide each of the sub-cases and this can be found in Appendix A.

Table 3 Overview of Case Studies

\begin{tabular}{lllll}
\hline & Product Category & $\begin{array}{c}\text { Launch } \\
\text { Year }\end{array}$ & Market Positioning & Description \\
\hline Case A & Task Chair: Joy & 2006 & Low-Mid Range & Adjustable, upholstered plastic back chair \\
\hline Case B & Visitor Chair: Cors & 2007 & Mid-High Range & Non-adjustable, stationary, plastic back chair \\
\hline Case C & Task Chair: Ara & 2009 & Mid-High Range & Adjustable, entirely plastic back chair \\
\hline Case D & Task Chair: Do & 2012 & Low-Mid Range & Adjustable, fabric mesh fixed to plastic chair back \\
\hline
\end{tabular}




\subsection{Case Activities}

\subsubsection{Interviews}

Tables 4 and Table 5 describe the stakeholder interviews, which were conducted in two stages.

Table 4 Internal Company Interviews

\begin{tabular}{|c|c|c|c|c|}
\hline Interviewee & $\begin{array}{l}\text { Stage 1: } \\
\text { Fact-finding } \\
\text { interview }\end{array}$ & $\begin{array}{l}\text { Stage 2: } \\
\text { In-Depth } \\
\text { Interview }\end{array}$ & $\begin{array}{l}\text { Relevant to } \\
\text { Case }\end{array}$ & Interview Topics \\
\hline Designer Manager & 1 & 1 & Case A & \multirow{6}{*}{$\begin{array}{l}\text { - Overview of product } \\
\text { - Company context at } \\
\text { outset of NPD } \\
\text { (related to eco- } \\
\text { initiatives) } \\
\text { - Eco-innovations } \\
\text { realised } \\
\text { - Reflection on targets } \\
\text { set compared with } \\
\text { final product } \\
\text { characteristics }\end{array}$} \\
\hline Designer & 1 & 1 & Case B & \\
\hline Designer & 1 & - & Case $\mathrm{C}$ & \\
\hline Design Manager & 1 & 1 & Case D & \\
\hline Senior Designer / Sustainability Lead & 1 & 1 & Case A,B,C,D & \\
\hline Design Manager / Ergonomist & - & 1 & Cases A,B,C,D & \\
\hline
\end{tabular}

Table 5 External Stakeholder Interviews (Interviews relevant to all cases)

\begin{tabular}{|c|c|c|c|c|}
\hline Interviewee & Stakeholder & $\begin{array}{l}\text { Stage 1: Site } \\
\text { Visit }\end{array}$ & Stage 2: Site Visit & Interview Topic \\
\hline Owner/Manager & $\begin{array}{l}\text { Injection Moulding - Tier } 1 \\
\text { Supplier }\end{array}$ & 1 & 1 & \multirow{2}{*}{$\begin{array}{l}\text { - Role in decision- } \\
\text { making during } \\
\text { product development } \\
\text { processes of each } \\
\text { case } \\
\text { - } \text { Discussion on key } \\
\text { decisions relevant to } \\
\text { ecodesign } \\
\text { - Evaluation of key } \\
\text { design features }\end{array}$} \\
\hline CEO & Injection Moulding - Tier 1 & 1 & 1 & \\
\hline Owner / Manager & Waste Management Provider & 1 & 1 & \multirow{3}{*}{$\begin{array}{l}\text { - Processes undertaken } \\
\text { (recycling, } \\
\text { disassembly) } \\
\text { - Evaluation of key } \\
\text { design features of } \\
\text { case products }\end{array}$} \\
\hline Owner / Manager & Waste Management Provider & 1 & - & \\
\hline Owner / Manager & Waste Management Provider & 1 & 1 & \\
\hline
\end{tabular}


The first stage focused on gathering information to develop further in-depth questions. The purpose of the internal company interviews was to build understanding of the decision-making processes during the NPD, for each of the four cases. The purpose of the external stakeholder interviews was to build understanding of the effects of design decisions across the product life cycle. Both sets of interviews took a semi-structured approach with open and closed questions. Interviews were recorded and transcribed, coded and analysed thematically. Three sets of interview questions for each of the main stakeholders (designer / supplier / waste management provider) can be found in Appendix B.

\subsubsection{Desk Research and Observations}

Desk research involved analysing documents including reviewing the design briefs, meeting minutes and project management files for each of the four cases. This allowed the aims for each NPD to be identified and assisted with uncovering the decision-making process during the NPD.

\subsubsection{Product Analysis}

Each product was analysed through the following methods:

- Abridged LCA was undertaken using streamlined off-the-shelf software, chosen for quick and readily implementable results, to support decision-making during NPD (Prendeville et al., 2013; Prendeville, 2015).

- Bills of materials assessment including: comparison of recycled content levels used in each product and their various parts; varieties and types of materials used; part and product mass for each product; evaluations of recyclability and reusability of parts and an assessment of 'downcycling' in the product (Prendeville, 2015).

- Reflective product evaluations were undertaken in discussion with the design lead for each project, through qualitative comparison of design briefs with the final design.

\section{Results}

This section describes the results of the four product case studies. Sections 4.1- 4.5 introduce the design approach for each of the four cases, the key factors influencing the firm's ecodesign decisions at that point and the main decisions taken. Section 4.5 describes the full set of ecodesign strategies for each of the four cases and includes a cross-case analysis. 


\subsection{Case A (Launched - 2006)}

\subsubsection{Design Approach}

The firm's main design objective was to replace an upholstered plywood chair design with a new upholstered plastic option, Joy (Fig. 2). In 2004, when the NPD was initiated, there were no specific ecodesign targets set at the outset of the project. Over the duration of the NPD, ecodesign strategies such as design for dis- and re-assembly were, retrospectively, integrated within the design brief. The reasons for this include, awareness of ecodesign within the team spurned through initial contact with the Ecodesign Centre (2005), as well as increasingly common client requests for carbon foot-print data. Design decisions were made in collaboration with two key local suppliers with whom the design team worked closely to realise key design features.

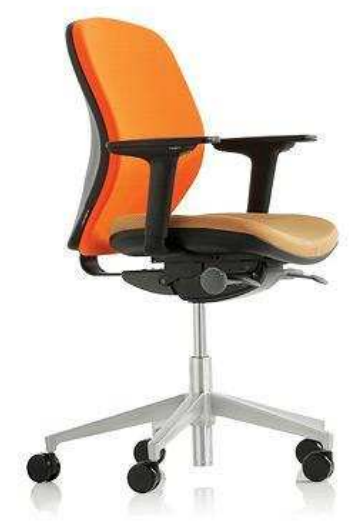

Fig. 2 Joy Task Chair

\subsubsection{Key Design Decisions - Efficiency}

Initially, the main focus for this NPD was to conceive a way to increase manufacturing efficiency by streamlining the assembly process through use of more plastics in the product. Previously, it manufactured chairs with moulded plywood chair backs; Polyurethane (PU) foam was glued to the plywood and this was then upholstered to make up the back of the chair. The market feedback was that plywood chairs, though aesthetically pleasing, did not have a long enough use life. This was because the upholstering would rip or wear exposing the seat foam and the plywood construction underneath. There was a market demand for more durable products 
than could be offered by an upholstered plywood chair and so the focus of design effort was on developing a new polypropylene (PP) seat and chair back. Switching materials improved assembly efficiency and new opportunities to design for disassembly could be seen (snap fits).

\subsection{Case B (Cors - Launched 2007)}

\subsubsection{Design Approach}

The firm's strategic design objective for this NPD was to design a durable visitor chair and the final product, Cors (Fig. 3), was launched in 2007. The durability criteria set out in the brief were required to satisfy the demanding end-user environments, typically schools and event halls. The project was led by a senior designer and for the first time, the NPD was fully-controlled by the in-house team. Ecodesign criteria were defined early in the design brief.

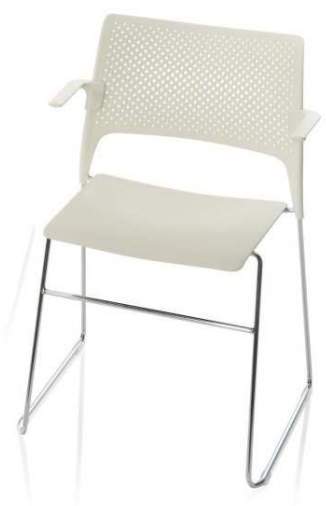

Fig. 3 Cors Visitor Chair

\subsubsection{Key Design Decisions - Durability}

Design for (manual) disassembly was defined as a key ecodesign target within the design brief. Yet this was sacrificed to realise the durability requirements in the product. To create a durable design, the nylon seat was moulded over the steel chair frame, so that the two main components in the chair are semi-permanently moulded together. To separate these two parts, during the NPD testing activities, an independent supplier purpose-built a fly-press rig to shear the nylon seat off the steel chair mainframe. The supplier described how the steel frame can be 'reused' whereas the nylon was 'reground for reprocessing' into a new test part (at the supplier's own premises). 
The nylon was chosen for its specific elasticity and recyclability properties. Through these design features, materials and manufacturing processes, the durability of the chair is achieved alongside design for recyclability characteristics. However, this synergy is achieved by foregoing the earlier ambition for manual disassembly.

\subsection{Case C (Ara - Launched 2009)}

\subsubsection{Design Approach}

This firm's strategic design aim was to design its 'most environmental chair' (defined in the design brief) and a number of ecodesign criteria were identified to realise this ambition. The Ara chair (Fig. 4) was launched onto the marked in 2009.

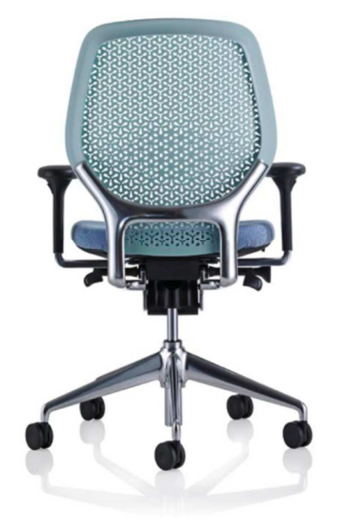

Fig. 4 Ara Task Chair

This NPD coincided with the firm participating in an Ecodesign Support Package ${ }^{1}$ which provided access to finance and specialist expertise to develop a new business offering in parallel to developing a product take-back system. With the financial support acquired through the Ecodesign Support Package, it C2C certified this new chair. This informed the design approach, which was centred on designing for recyclability and reducing toxicity of materials through supplier collaborations. By this time carbon foot-printing was a standard activity within the NPD process. However, this carbon foot-printing was use predominantly for marketing purposes. It was also used as an early indicator of the chair's environmental performance in comparison with other chairs in the portfolio.

\footnotetext{
${ }^{1}$ Hosted by the Ecodesign Centre, Wales, funded by the Welsh government.
} 


\subsubsection{Key Design Decisions - Recyclability}

The firm's evolving knowledge of ecodesign influenced its decisions during this NPD. Previous 'mistakes' where parts were co-moulded seemingly needlessly, stimulated a commitment to avoid co-moulded design features from this point onwards. Material streamlining to facilitate closed material loops through accumulation of clean 'material banks' was driven by its commitment to $\mathrm{C} 2 \mathrm{C}$, as well as a wider market trend towards $\mathrm{C} 2 \mathrm{C}$ certification within the office furniture sector (see Lee \& Bony, 2008). Upon recommendation from McDonough Braungart Design Chemistry, the materials chosen for this chair focused on recyclability, specifically aluminium was recommended as a 'technical nutrient' suited to perpetual, closed loop recycling. This had an impact on wider decisions about the product. For instance, due to the high cost of the aluminium material the cast manufacturing was outsourced to a supplier in the Far East. The environmental impact of the chair was assessed and based on the company's own carbon footprint analysis, as well as through abridged LCA, is higher than those chairs described in cases $\mathrm{A}$ and $\mathrm{D}$ (Table 2). This revealed a paradox, an apparent contradiction, between the $\mathrm{C} 2 \mathrm{C}$ paradigm's recommendations and the LCA results.

\subsection{Case D (Do - Launched 2012)}

\subsubsection{Design Approach}

At the firm, the market trend to simplify chair aesthetics influenced its strategic design aim to streamline and reduce ergonomic controls on this product, focusing on an evolution of the chair which switched from hard plastics to mesh fabrics, Do (Fig. 5). One effect of the high environmental impact of the Ara chair (Case C - Section 4.3.1), led to 'dematerialisation' of the product (light-weighting) becoming a key design objective for this NPD. This move towards 'dematerialising' the chair was expected to reduce its carbon footprint while also meeting the market demands. Abridged LCA was increasingly used during the design processes, predominantly to make comparisons between similar products within the firm portfolio. 


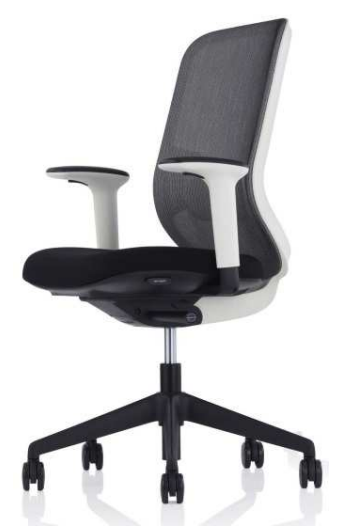

Fig. 5 Do Chair

\subsubsection{Key Design Decisions - Light-weighting}

The design team opted for familiar and reliable materials, which they had previously used. The light-weighting of the product was measured against Joy (Case A) and was achieved by integrating functionality and streamlining the back of the chair, the chair's motion mechanism and back frame. A chair mechanism was purchased from a sub-supplier as a 'standard' off-theshelf component with whom the design team worked closely to customize, removing parts not necessary for this product. It transpired that, though the product is lighter overall, the bills of materials analysis (Table 2) found that this product has a lower quantity of recycled material and a higher quantity of virgin material than that in case A, yet still has the lowest environmental impacts. This raised questions about the interplay between resource efficiency strategies (such as light-weighting) with the overall environmental impacts of the product. It also led to the systematic measurement of quantities of recycled content and virgin materials in the bills of materials across the product portfolio.

\subsection{Cross-case Analysis: Ecodesign Dilemmas Identified in the Cases}

Table 6 describes the ecodesign criteria defined in the design brief, the product eco-innovations realised and the dilemmas identified across each of the cases A, B, C, D. In Table 6 the trajectory of the firm's ecodesign decision-making can be observed. We see how the design team initiated ecodesign through product design strategies (eg in cases A and B through dis- and re-assembly or durability) to using formalised approaches offered by external collaborators (such as the $\mathrm{C} 2 \mathrm{C}$ Design Protocol used in Case C) and finally we see a shift back to efficiency strategies (case D). 
It reflects the difficulty of incorporating all ecodesign principles simultaneously in one design and the multi-level nature of dilemmas observed (eg operational, strategic, life-cycle oriented).

Table 6 Summary of Ecodesign Strategies, Eco-Innovations and Dilemmas Identified

\begin{tabular}{|c|c|c|c|}
\hline Case & $\begin{array}{l}\text { Ecodesign Strategies } \\
\text { Defined in the Brief }\end{array}$ & Product Eco-Innovations Realised & Dilemma Description \\
\hline \multirow[t]{3}{*}{ A } & Design for Assembly & \multirow{2}{*}{$\begin{array}{l}\text { Gluing replaced with a co-moulding process to } \\
\text { - assemble the seat foam to a plastic seat back }\end{array}$} & \multirow{2}{*}{$\begin{array}{l}\text { This creates a composite part of two different materials that are } \\
\text { difficult and uneconomical to separate }\end{array}$} \\
\hline & Design for Durability & & \\
\hline & $\begin{array}{l}\text { Design for Dis- and } \\
\text { Re-Assembly }\end{array}$ & Snap fits replace screws in new plastic parts. & $\begin{array}{l}\text { Snap fits decrease dis- and assembly time improving efficiency - } \\
\text { achieved by substitution plywood with PP, yet, the plywood has a } \\
\text { lower carbon impact and abridged LCA score }\end{array}$ \\
\hline \multirow[t]{4}{*}{ B } & Design for Durability & $\begin{array}{l}\text { Nylon seat is moulded over a steel rod frame } \\
\text { increasing the strength in the fracture joints }\end{array}$ & $\begin{array}{l}\text { Design for Disassembly - over-moulding the parts means } \\
\text { disassembly is only possible by shearing the nylon off the steel rod } \\
\text { frame thereby damaging the part integrity }\end{array}$ \\
\hline & & & $\begin{array}{l}\text { Material Streamlining - a range of plastics required to achieve } \\
\text { durability performance required }\end{array}$ \\
\hline & $\begin{array}{l}\text { Design for } \\
\text { Recyclability }\end{array}$ & $\begin{array}{l}\text { Nylon seat moulded over a steel rod frame } \\
\text { increases strength in the fracture joints and } \\
\text { reduces need for glass fillers in the plastic } \\
\text { thereby improving its recyclability }\end{array}$ & $\begin{array}{l}\text { Design for Disassembly - co-moulding the parts foregoes manual } \\
\text { disassembly, shearing the nylon off the steel rod frame through a } \\
\text { bespoke rig, damaging part integrity }\end{array}$ \\
\hline & Material substitution & $\begin{array}{l}\text { An expensive high strength nylon is opted for } \\
\text { to achieve durability in plastic parts }\end{array}$ & $\begin{array}{l}\text { Recycled content inclusion - recycled content material of the same } \\
\text { grade of the nylon used is unavailable to the supplier }\end{array}$ \\
\hline \multirow[t]{5}{*}{$\mathbf{C}$} & $\begin{array}{l}\text { Design for } \\
\text { Disassembly }\end{array}$ & $\begin{array}{l}\text { Tongue and groove assembly design feature } \\
\text { allows for fastener-free disassembly and re- } \\
\text { assembly of two major plastic components. }\end{array}$ & $\begin{array}{l}\text { Recyclability - 'New' strong plastic material which facilitates this } \\
\text { design, has 'low' recyclability on account of reinforcing glass } \\
\text { fibres, which are sheared during recycling, reducing the material's } \\
\text { strength and overall performance } \\
\text { Durability - overall durability of part assembly is reduced - } \\
\text { fasteners reintroduced to reinforce assembly }\end{array}$ \\
\hline & Avoid Co-mouldings & $\begin{array}{l}\text { Two grades of elastomer moulded together to } \\
\text { create an arm control that is strong with an } \\
\text { aesthetic 'soft-touch' finish }\end{array}$ & $\begin{array}{l}\text { Recyclability - expert assessment of the recyclability (two grades } \\
\text { of the same material) found that different grades have different } \\
\text { melting temperatures making recycling problematic }\end{array}$ \\
\hline & $\begin{array}{l}\text { Increase Recycled } \\
\text { Content }\end{array}$ & The inner arm pad uses reconstituted PU foam & Durability - through reduced physical properties \\
\hline & $\begin{array}{l}\text { Material Selection for } \\
\text { Recyclability }\end{array}$ & $\begin{array}{l}\text { The chair uses aluminium rather than plastic in } \\
\text { the base as well as in the back to foster greater } \\
\text { recyclability. }\end{array}$ & $\begin{array}{l}\text { Energy - Replacing plastic with aluminium requires additional } \\
\text { polishing process, which increases the production energy use } \\
\text { High cost of aluminium - casting processes outsourced to Far East } \\
\text { increasing transport }\end{array}$ \\
\hline & C2C Design Protocol & $\begin{array}{l}\text { Toxicity Reduction: (1) Reformulated grease } \\
\text { and oil used during processes } \\
\text { (2) New PU seat foam formulation developed } \\
\text { with lower Volatile Organic Compounds }\end{array}$ & $\begin{array}{l}\text { LCA results show high environmental impacts for this product } \\
\text { when compared with similar products in the firm's portfolio. }\end{array}$ \\
\hline \multirow[t]{5}{*}{$\mathrm{D}$} & Dematerialise & $\begin{array}{l}\text { Finite Element Analysis used during NPD to } \\
\text { reduce materials by } 18 \% \text { in comparison to its } \\
\text { market predecessor (case A) }\end{array}$ & $\begin{array}{l}\text { Recyclability - Reduced opportunities for recycled content } \\
\text { inclusion on account of the stress on dematerialised parts }\end{array}$ \\
\hline & & Part integration reduces part count & Recyclability - increase in composite material use for strength \\
\hline & & & $\begin{array}{l}\text { Product has highest mass of virgin material of all four products - } \\
\text { paradoxical outcome, in light of strategy to dematerialise }\end{array}$ \\
\hline & Material Streamlining & $\begin{array}{l}\text { Assembly of PET mesh, thread and gasket in } \\
\text { the back of the chair thought to generate a } \\
\text { mono-material well suited to recycling }\end{array}$ & $\begin{array}{l}\text { Final assembly generates combination of PET materials of differen } \\
\text { grades - which negatively impacts recyclability due to varying } \\
\text { melt temperatures }\end{array}$ \\
\hline & & & Additional heat process required for tensioning mesh \\
\hline
\end{tabular}




\section{Analysis \& Discussion}

\subsection{Uncovering Ecodesign Dilemmas}

In this section, we categorise the ecodesign dilemmas identified within both the literature (Table 1) and the case studies (Table 6) according to the operational, tactical and strategic decisionmaking framework described by Brones et al., (2015). Combining these data-sets allowed for the development of a new classification of ecodesign dilemmas according to the unique set identified. Fig. 6 illustrates and defines this new framework. Table 7 shows the analysis hierarchies between multiple strategies are denoted by the hatched areas and solid lines in the left-most column. The unique set of dilemmas identified through the analysis are defined as:

- Tensions - bilateral tensions between two ecodesign strategies

- Hierarchies - synergies and preclusions between two or more ecodesign strategies where a single dominant strategy, or reinforcing synergies, precludes others

- Contradictions - ecodesign strategies lead to unintended increases in environmental impacts, or, paradoxical outcomes are observed in approaches to sustainable innovation

- Oversights - emphasis on one ecodesign strategy disavows other potentially synergistic ones causing blind spots in ecodesign decision-making

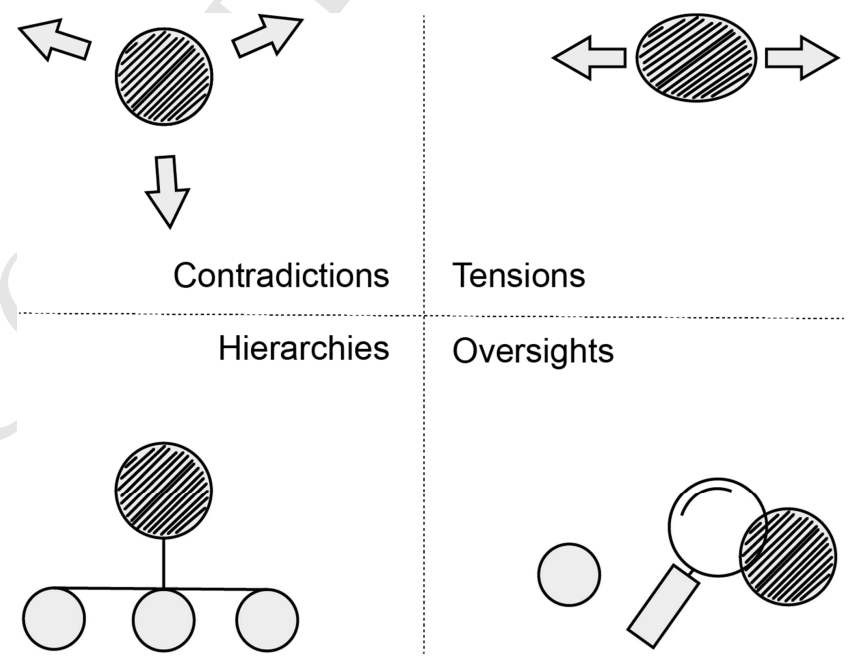

Fig. 6 Classification of Ecodesign Dilemmas 
Table 7 Analysis according to Brones et al., (2015) with a Classification of Unique Ecodesign Dilemmas

\begin{tabular}{|c|c|c|c|}
\hline Strategy & Dilemma Description & Classification & Decision-level \\
\hline Design Assembly & \multirow{2}{*}{$\begin{array}{l}\text { Disassembly - This creates a composite part of two different } \\
\text { materials that are difficult and uneconomical to separate }\end{array}$} & Tension & Tactical \\
\hline Design for Durability & & Tension & Tactical / Strategic \\
\hline $\begin{array}{l}\text { Design for Dis- and Re- } \\
\text { Assembly }\end{array}$ & $\begin{array}{l}\text { Snap fits decrease dis- and assembly time improving efficiency } \\
\text { - achieved by replacing plywood with PP, yet, the plywood has } \\
\text { a lower abridged LCA score }\end{array}$ & Contradiction & Operational \\
\hline \multirow[t]{2}{*}{ Design for Durability } & $\begin{array}{l}\text { Disassembly - over-moulding the parts means disassembly is } \\
\text { only possible by shearing the nylon off the steel rod frame } \\
\text { thereby damaging the part integrity }\end{array}$ & Tension & Operational \\
\hline & $\begin{array}{l}\text { Material Streamlining - a range of plastics required to achieve } \\
\text { durability performance required }\end{array}$ & Tension & $\begin{array}{l}\text { Operational / } \\
\text { Tactical }\end{array}$ \\
\hline Design for Recyclability & $\begin{array}{l}\text { Design for Disassembly - co-moulding the parts foregoes } \\
\text { manual disassembly, shearing the nylon off the steel rod frame } \\
\text { through a bespoke rig, damaging part integrity }\end{array}$ & Tension & Operational \\
\hline Material substitution & $\begin{array}{l}\text { Recycled content inclusion - recycled content material of the } \\
\text { same grade of the nylon is unavailable to the supplier }\end{array}$ & Tension & Operational \\
\hline \multirow[t]{3}{*}{ Design for Disassembly } & $\begin{array}{l}\text { Recyclability - 'New' high strength plastic used to facilitate new } \\
\text { design, has 'low' recyclability on account of reinforcing glass } \\
\text { fibres, which are sheared during recycling, reducing the } \\
\text { material's strength and overall performance }\end{array}$ & Tension & Operational \\
\hline & Durability - overall durability of part assembly is reduced - & Tension & $\begin{array}{l}\text { Operational / } \\
\text { Tactical }\end{array}$ \\
\hline & $\begin{array}{l}\text { Due to reduced durability additional manufacturing process re- } \\
\text { introduced to fix parts with fasteners }\end{array}$ & Oversight & $\begin{array}{l}\text { Operational / } \\
\text { Tactical }\end{array}$ \\
\hline Avoid Co-mouldings & $\begin{array}{l}\text { Recyclability - expert assessment of the recyclability indicates } \\
\text { that different grades of the same material have different melting } \\
\text { temperatures making recycling problematic }\end{array}$ & Tension & $\begin{array}{l}\text { Operational / } \\
\text { Tactical }\end{array}$ \\
\hline $\begin{array}{l}\text { Increase Recycled } \\
\text { Content }\end{array}$ & Durability - through reduced physical properties & Tension & $\begin{array}{l}\text { Operational / } \\
\text { Tactical }\end{array}$ \\
\hline \multirow[t]{2}{*}{$\begin{array}{l}\text { Material Selection for } \\
\text { Recyclability }\end{array}$} & $\begin{array}{l}\text { Energy - Replacing plastic with aluminium requires additional } \\
\text { polishing process, which increases the production energy use }\end{array}$ & Oversight & Operational \\
\hline & $\begin{array}{l}\text { High cost of aluminium - casting processes outsourced to Far } \\
\text { East increasing transport }\end{array}$ & Contradiction & Strategic \\
\hline C2C Design Protocol & $\begin{array}{l}\text { LCA measures high environmental impacts for this product when } \\
\text { compared with similar products in the firm's portfolio. }\end{array}$ & Contradiction & Tactical / Strategic \\
\hline \multirow[t]{3}{*}{ Dematerialise } & $\begin{array}{l}\text { Recyclability - Reduced opportunities for recycled content } \\
\text { inclusion on account of the stress on dematerialised parts }\end{array}$ & Tension & Operational \\
\hline & Recyclability - increase in composite material use for strength & Tension & Operational \\
\hline & $\begin{array}{l}\text { Product has highest mass of virgin material of all four products - } \\
\text { paradoxical outcome, in light of strategy to dematerialise }\end{array}$ & Contradiction & Operational \\
\hline \multirow[t]{2}{*}{ Material streamlining } & $\begin{array}{l}\text { Assembly combines PET materials of different grades - } \\
\text { negatively impacts recyclability due to varying melt temperatures }\end{array}$ & Tension & Operational \\
\hline & Additional heat process required for tensioning new fabric mesh & Oversight & $\begin{array}{l}\text { Operational / } \\
\text { Tactical }\end{array}$ \\
\hline Durability & $\begin{array}{l}\text { More mass of material to strengthen parts, which reduces } \\
\text { material efficiency }\end{array}$ & Tension & Strategic \\
\hline $\begin{array}{l}\text { Design for repair, } \\
\text { remanufacturing }\end{array}$ & Newly manufactured products may be more energy efficient & Contradiction & Strategic $^{*}$ \\
\hline Light-weighting & $\begin{array}{l}\text { Requires composite material which in turn negatively affects } \\
\text { recyclability }\end{array}$ & Tension & Operational $^{*}$ \\
\hline Design for Recyclability & $\begin{array}{l}\text { Shortens product and/or part lifetime due to lower quality which } \\
\text { can lead to early part or product failure }\end{array}$ & Contradiction & Strategic $^{*}$ \\
\hline
\end{tabular}

* Denotes instances taken from literature and therefore decision-level is assumed 


\subsection{Ecodesign - Fuelling Business Model Innovation}

Table 8 summarises the main ecodesign dilemmas identified in each of the four cases, the core design approach, key factors affecting the firm's decision-making and the critical learning points observed. It shows the dominant dilemmas for each case and the main effect these had on the companies decision-making at the time. This shows how the firm's ecodesign focus gradually shifted from product design to seeing the business model as a key consideration to rationalise its ecodesign strategy.

Table 8. Key Transition Phases towards Business Model Innovation (Nine-year Timeline)

\begin{tabular}{|c|c|c|c|c|}
\hline Case & $\begin{array}{l}\text { Main Dilemmas } \\
\text { Observed }\end{array}$ & Design Approach & Influencing Factors & Learning Points \\
\hline $\bar{A}$ & $\begin{array}{l}\text { Tensions - } \\
\text { Design for efficient } \\
\text { assembly precludes } \\
\text { easy manual } \\
\text { disassembly to keep } \\
\text { parts in-tact }\end{array}$ & $\begin{array}{l}\text { Efficiency-led - } \\
\text { Focus on recyclate and } \\
\text { recyclability, efficient } \\
\text { manufacturing }\end{array}$ & $\begin{array}{l}\text { - External partnerships initiate } \\
\text { ecodesign process } \\
\text { - Customer requests } \\
\text { - Localised manufacturing base }\end{array}$ & $\begin{array}{l}\text { - Growing ecodesign awareness } \\
\text { - Single indicators perceived as } \\
\text { deficient approach }\end{array}$ \\
\hline $\mathrm{B}$ & $\begin{array}{l}\text { Hierarchies - } \\
\text { durability and } \\
\text { recyclability work } \\
\text { in-tandem yet } \\
\text { preclude in-tact part } \\
\text { disassembly }\end{array}$ & $\begin{array}{l}\text { Durability-led - } \\
\text { Focus on durability, } \\
\text { design for Long-life }\end{array}$ & $\begin{array}{l}\text { - Increasing awareness of third- } \\
\text { party after-market resales } \\
\text { through remanufacturing / } \\
\text { leasing } \\
\text { - Increasing awareness of } \\
\text { design for disassembly }\end{array}$ & $\begin{array}{l}\text { - Incompatibility between } \\
\text { strategies means some 'twin' } \\
\text { and others are mutually } \\
\text { exclusive }\end{array}$ \\
\hline $\mathrm{C}$ & $\begin{array}{l}\text { Contradictions - } \\
\text { LCA results and } \\
\text { C2C guidance } \\
\text { appear } \\
\text { contradictory }\end{array}$ & $\begin{array}{l}\text { Efficiency-led - } \\
\text { C2C certification drives } \\
\text { focus on recyclate, } \\
\text { recyclability }\end{array}$ & $\begin{array}{l}\text { - Wider sector trends } \\
\text { - Insights from previous NPDs } \\
\text { - Learning from partnerships } \\
\text { with external experts }\end{array}$ & $\begin{array}{l}\text { Business context perceived } \\
\text { critical for rational design } \\
\text { approach (some strategies } \\
\text { more-or-less suited to certain } \\
\text { business contexts) }\end{array}$ \\
\hline $\bar{D}$ & $\begin{array}{l}\text { Oversights - } \\
\text { Design for 'light- } \\
\text { weighting' in } \\
\text { conflict with } \\
\text { resource efficiency }\end{array}$ & $\begin{array}{l}\text { Twinned approach - } \\
\text { focus on durability and } \\
\text { light-weighting in } \\
\text { tandem }\end{array}$ & $\begin{array}{l}\text { High impacts of aluminium } \\
\text { (identified through LCA of } \\
\text { case B) lead to a focus on } \\
\text { light-weighting } \\
\text { - Expanding knowledge of } \\
\text { importance of business model }\end{array}$ & $\begin{array}{l}\text { - Need for multiple evaluation } \\
\text { indicators and review criteria } \\
\text { - Measures of recycled content } \\
\text { systematically integrated in } \\
\text { product bills of materials }\end{array}$ \\
\hline
\end{tabular}

In the cases presented, we empirically describe the evolution of ecodesign in a single firm to complement emerging theoretical frameworks derived by other authors (Zhang et al., 2013; 
Brones et al., 2016). Nevertheless, in this case, the process is self-determined and transitional, unfolding over a timeframe of nine years. In 2005, the firm initiated ecodesign at the operational level (through initial adoption of ecodesign strategies), with a gradual evolution and integration of tactical managerial processes over consecutive NPDs (key performance indicators, review stages). Eventually by 2014, it was beginning to systematically consider new business models, in particular a product-service-system approach. This involved piloting a new remanufacturing offering through either direct-sales or leasing products to customers. This is because it was found that, the business model contextualises ecodesign decisions. For instance, at the conceptual stages of the NPD, described in case C, the firm set out to design its 'most environmental chair' which it believed could be enabled by a C2C certification. However, abridged LCA found that this chair actually has comparatively high environmental impacts when taken in the context of a direct-sales business model (Prendeville et al., 2013, 2015), where multiple product life cycles are not proactively managed by the firm.

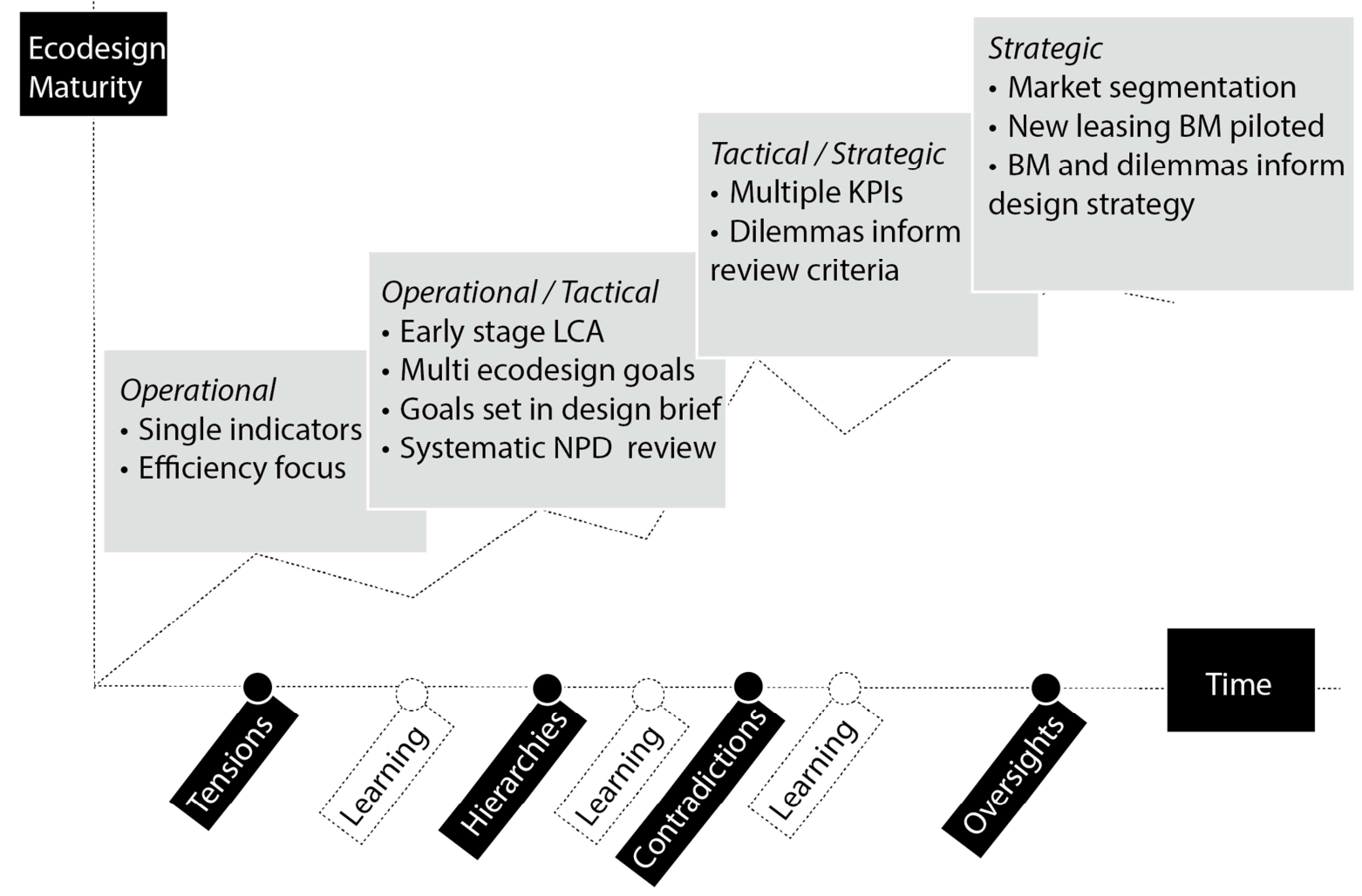

Fig. 7. Key Ecodesign Dilemmas and Transition Phases towards Business Model Innovation $($ KPI = Key Performance Indicators, BM = Business Model $)$ 
The firm's evolution, described as its learning experiences and key transitional phases, can be identified and are described in Fig. 7 (derived from the conceptual framework defined in Fig. 1). This illustration of the firm's trajectory shows how it moves from operational actions to tactical to eventually consider strategic business elements, in this case piloting a new business model, as important for its ecodesign approach. The key characteristics of each phase are as follows:

\section{Exploring Phase (operational) - inspired yet ad-hoc and spontaneous actions}

○ Focus on efficiency measures (dis- and re-assembly for recycling / durability)

2 Evolving Phase (tactical) - initial learnings starting to become internalised

○ Semi-integrated approach driven bottom-up by design team

- Ecodesign criteria systematically defined in design brief

○ Combination and application of multiple ecodesign strategies

- Carbon foot-printing used for external communications

3 Embedding Phase (strategic) - careful evaluation and reflection are characteristic

- Focus on scaling processes systematically across product portfolio

- Early stage LCA undertaken systematically across product portfolio

○ Needs for multiple indicators recognized (environmental and efficiency measures)

- $\mathrm{C} 2 \mathrm{C}$ principles internalised

4 Unifying Phase (operational, tactical and strategic) - ecodesign actions are responsive to strategic imperative

- Ecodesign strategy and business model perceived as co-dependent

While this broadly summarises its process of ecodesign actions and learning, the phases described here are not rigid and distinct but rather unfolded in an organic, overlapping and iterative way. The framework in Fig. 8 shows the typical actions taken and the different types of ecodesign dilemmas that can be managed through either operational, tactical and strategic actions. A combination of operational, tactical and strategic activities are needed for firms to systematically manage all types of ecodesign dilemmas identified. 


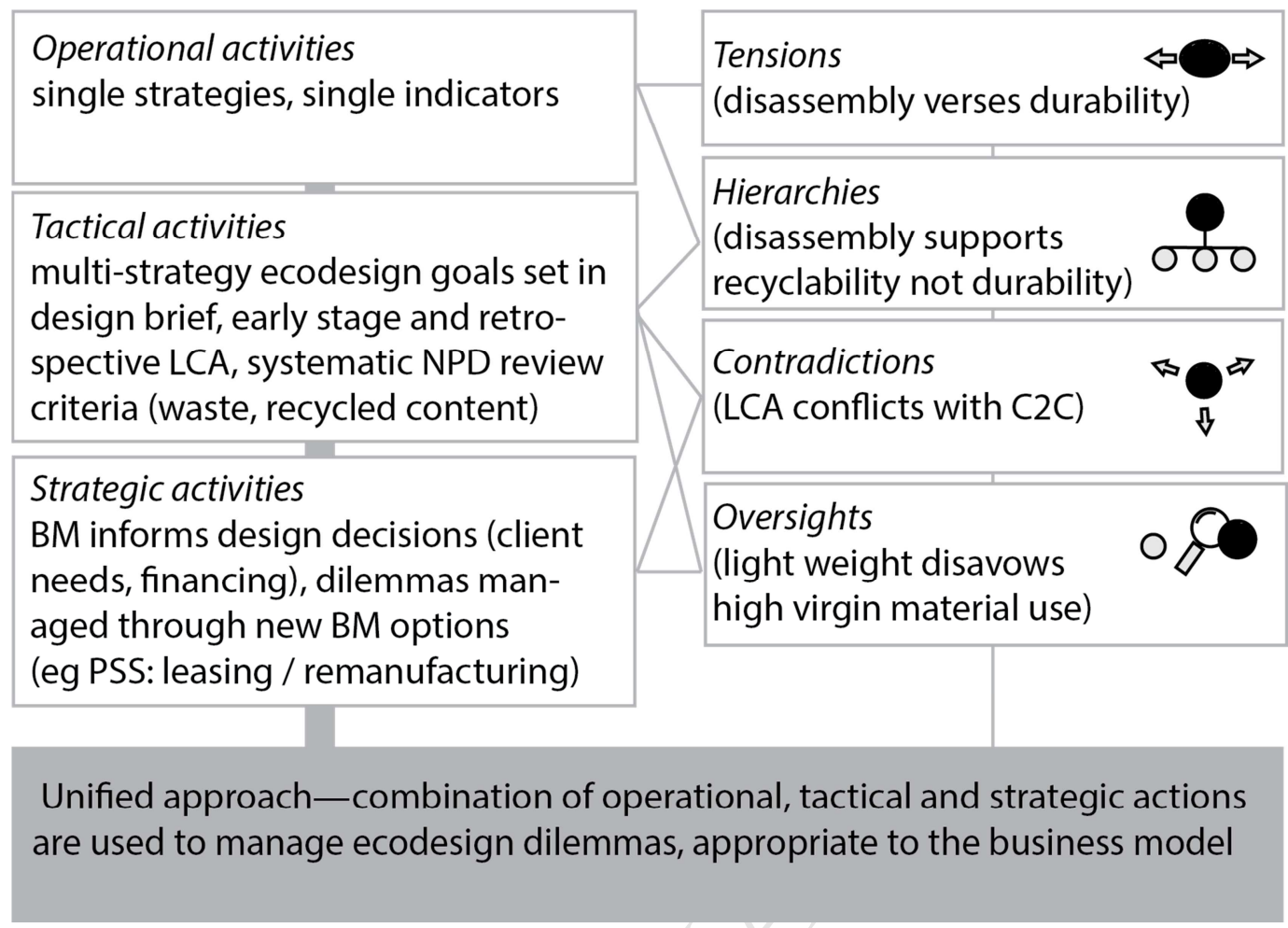

Fig. 8 Unified Approach to Managing Ecodesign Dilemmas - Operational, Tactical, Strategic

\subsection{Contributions, Limitations and Further Work}

The conclusions presented here are based on an in-depth case-study at a single firm and therefore the results have limitations. However, Eisenhardt and Graebner (2007) and Yin (2003) recognise that single case studies may be chosen because they are revelatory, provide extreme exemplars, or provide particular opportunities for unusual research access. This study presented opportunities to conduct empirical research on an exemplary case of ecodesign decision-making in practice, at a small-to-medium sized enterprise, over an extended time-frame.

The action research method prioritised action and implementation at the case company and at times the lead researcher was immersed in its day-to-day activities. This allowed for rich data collection but can also cause researcher bias. Therefore, the reliability of the study was fostered through the use of a case protocol (Yin, 2003), through the use of multiple data sources within the firm and externalising the results through scientific validation (with expert material scientists and LCA experts). Such approaches also support the independence of the study, which is also important in light of the collaborative action research methodology chosen. 
This research focuses on dilemmas linked to ecodesign strategies relevant to office furniture as adopted by the firm. Other dilemmas exist that pose barriers to innovation, which are influenced by a broad range of factors (organisational, market-based, cultural, supply chain influences) and are therefore important for companies to consider. Further research would consider dilemmas across a range of product categories, the broad set of factors influencing decision-making (markets, competitors), as well as a broad set of design criteria (functional characteristics, cost) as well as systematically assessing decisions with respect to the product life-cycle (from material extraction to the end-of-life). Despite these limitations, the results are insightful for the wider discipline. The main academic contributions include:

- Empirically describing a long-term ecodesign case study to complement theoretical work on ecodesign maturity modelling (Pigosso et al., 2013) and ecodesign transition frameworks (Brones et al., 2014; Bonou et al., 2016)

- Illustrating the practitioner's perspective on how ecodesign dilemmas are negotiated in practice building on previous work by Byggeth and Hoschorner (2007)

- Developing a new classification of ecodesign dilemmas (Fig. 6) and integrating this with the concept of business model innovation (Fig. 7, 8)

From an industrial viewpoint, the research offers insights into how an ecodesign process unfolds in an applied setting, sharing practices for industrial benchmarking.

\section{Conclusion}

The aim of this article was to explore ecodesign dilemmas from a constructivist viewpoint: How do ecodesign dilemmas relate to a firm's ecodesign evolution? Four case studies of NPD outline a single firm's path to strategic ecodesign decision-making that led it to business model innovation. From the cases a unique set of ecodesign dilemmas is defined: tensions, hierarchies, contradictions and oversights. These dilemmas are identified through four transitions phases at the case firm: exploring; evolving; embedding; unifying. This evolution shows how firms need to adopt a unified approach, combining operational (ecodesign principles approach), tactical (management processes: NPD goals, review criteria) and strategic actions (business model 
innovation) to systematically manage the range of ecodesign dilemmas they encounter. From this, we develop a framework describing key actions according to operational, tactical and strategic ecodesign and the types of ecodesign dilemmas typical to each approach. Importantly, the business model is shown to contextualise ecodesign dilemmas. Managing ecodesign dilemmas is a key aspect of an effective ecodesign strategy, that can be more clearly understood when the business model is considered. In light of this, the frameworks defined in this study are important tools for further work.

Finally, we see how the strategic integration of ecodesign in firms can be evolutionary. In this firm, the process started with the use of basic ecodesign principles, eventually leading to a pilot study for business model innovation. This happened because the design team's actions fuelled cycles of learning that stimulated this need for business model innovation. This means that design can drive sustainable change in firms, from the bottom-up, towards new business models.

\section{Acknowledgements}

This work was in part-funded by the European Social Fund under the European Regional Development Fund. The authors would like to thank the participating firm for its collaboration, the journal's subject editor and a number of anonymous reviewers whose input at the early stages of the article has been invaluable.

\section{References}

Al-Oqla, F. M., \& Sapuan, S. M. (2015). Polymer Selection Approach for Commonly and Uncommonly Used Natural Fibers Under Uncertainty Environments. JOM, 67(10), 2450-2463.

Al-Oqla, F. M., Sapuan, M. S., Ishak, M. R., \& Aziz, N. A. (2014). Combined multi-criteria evaluation stage technique as an agro waste evaluation indicator for polymeric composites: Date palm fibers as a case study. BioResources, 9(3), 4608-4621.

Ashby, M. F., 2011. Materials Selection in Mechanical Design. Chp. 7. Multiple Constraints and Conflicting Objectives. pp. 197-216. http://doi.org/10.1016/B978-1-85617-663-7.00007-2

Bakker et al., 2014. Products That Last: Product Design for Circular Business Models. First Edition. TU Delft Library.

Bakker, C. et al., 2012. Rethinking Eco-design Priorities: the case of the Econova television. In Electronics Goes Green, Taking Green to the Next Level. Berlin, Germany: Fraunhofer-Verlag.

Baumann, H., Boons, F. \& Bragd, A., 2002. Mapping the green product development field: engineering, policy and business perspectives. Journal of Cleaner Production, 10, pp.409-425.

Besch, K., 2005. Product-service systems for office furniture: barriers and opportunities on the European market. Journal of Cleaner Production, 13(10-11), pp.1083-1094. 
Bocken, N., Allwood, J., Willey, A., King, J. 2011. Development of an eco-ideation tool to identify stepwise greenhouse gas emissions reduction options for consumer goods. Journal of Cleaner Production. 19 (12), pp. 1279-1287.

Bocken, N. M. P., Short, S. W., Rana, P., \& Evans, S. (2014). A literature and practice review to develop sustainable business model archetypes. Journal of cleaner production, 65, 42-56.

Bonou, A., K. Skelton, and S.I. Olsen. 2016. Ecodesign framework for developing wind turbines. Journal of Cleaner Production: 1-11. http://dx.doi.org/10.1016/j.jclepro.2016.02.093.

Boons, F., \& Lüdeke-Freund, F. (2013). Business models for sustainable innovation: state-of-the-art and steps towards a research agenda. Journal of Cleaner Production, 45, 9-19.

Borchardt, M. et al., 2012. Ecodesign Case Studies for Furniture Companies Using The Analytic Hierarchy Process. International Journal of Industrial Engineering: Theory, Applications and Practice, 19(8).

Bovea, M.D. \& Pérez-Belis, V., 2012. A taxonomy of ecodesign tools for integrating environmental requirements into the product design process. Journal of Cleaner Production, 20(1), pp.61-71.

Braungart, M., McDonough, W., \& Bollinger, A. (2007). Cradle-to-cradle design: creating healthy emissions-a strategy for ecoeffective product and system design. Journal of cleaner production, 15(13), 1337-1348.

Brennan, G., Tennant, M., \& Blomsma, F., 2015. Business and Production Solutions 10: Closing Loops and the Circular Economy, in: Kopnina, H., \& Shoreman-Ouimet, E., Sustainability, Key Issues. Earthscan Routledge: 210

Brezet, H. \& Van Hemel, C., 1997. Ecodesign: a promising approach to sustainable production and consumption., Paris.

Brones, F., M.M. De Carvalho, and E.D.S. Zancul. 2014. Ecodesign in project management : a missing link for the integration of sustainability in product development ? Journal of Cleaner Production 80: 106-118. http://dx.doi.org/10.1016/j.jclepro.2014.05.088.

Brones, F. and M. Monteiro De Carvalho. 2015. From 50 to 1: Integrating literature toward a systemic ecodesign model. Journal of Cleaner Production 96: pp. 44-47. http://dx.doi.org/10.1016/j.jclepro.2014.07.036.

Bryman, A., \& Bell, E. 2015. Business research methods. Oxford University Press, USA.

Byggeth, S. \& Hochschorner, E., 2006. Handling trade-offs in Ecodesign tools for sustainable product development and procurement. Journal of Cleaner Production, 14(15-16), pp.1420-1430.

Carlos, J., Garcia, C. \& Filho, E.R., 2008. Ecodesign method for office furniture with emphasis on information gathering for product environmental improvement. , 6(June), pp.39-44.

Centre for European Policy Studies. (2014). Bolognini A. The EU Furniture Market Situation and a Possible Furniture Products Initiative. Final Report submitted to the European Commission DG Enterprise and Industry. Brussels.

Collado-Ruiz, D. \& Ostad-Ahmad-Ghorabi, H., 2013. Estimating Environmental Behavior Without Performing a Life Cycle Assessment. Journal of Industrial Ecology, 17(1), pp.31-42.

Costa, F., Prendeville, S., Beverley, K., Teso, G., \& Brooker, C. (2015). Sustainable product-service systems for an office furniture manufacturer: how insights from a pilot study can inform PSS design. Procedia CIRP, 30, 66-71.

Dekoninck E.A., Domingo L., O'Hare J.A., Pigosso D.C.A., Reyes T., Troussier N,. 2016. Defining the challenges for ecodesign implementation in companies: development and consolidation of a framework, Journal of Cleaner Production. doi: 10.1016/j.jclepro.2016.06.045.

Deutz, P., McGuire, M., \& Neighbour, G. 2013. Eco-design practice in the context of a structured design process: An interdisciplinary empirical study of UK manufacturers. Journal of Cleaner Production, 39, pp. 117-128. http://doi.org/10.1016/j.jclepro.2012.08.035

Domingo, L., M. Buckingham, E. Dekoninck, and H. Cornwell. 2015. The importance of understanding the business context when planning eco-design activities. Journal of Industrial and Production Engineering 32(1): pp. 3-11. http://www.tandfonline.com.gaelnomade.ujf-grenoble.fr/doi/abs/10.1080/21681015.2014.1000398. 
Eisenhardt, K.M. \& Graebner, M.E., 2007. Theory Building from Cases: Opportunities and Challenges. ACAD Manage J, 50(1), pp.25-32.

European Commission. 2012. Ecodesign Your Future. How ecodesign can help the environment by making products smarter. Available at: http://bookshop.europa.eu/en/ecodesign-your-futurepbNB3112737/?CatalogCategoryID=EhEKABstLQkAAAEjyZAY4e5L

Fiksel, J., 1993. Design for environment: an integrated systems approach. Proceedings of the 1993 IEEE International Symposium on Electronics and the Environment.

Furniture Industry Research Association. 2011. A study into the feasibility of Benchmarking carbon footprints of furniture products.

Gamage, G.B., Boyle, C. \& McLaren, J., 2007. Life Cycle Assessment of Commercial Furniture: A Case Study of Formway LIFE Chair. International Journal of Life Cycle Assessment, pp.119-124.

Gibson, R. B. 2013. Avoiding sustainability trade-offs in environmental assessment. Impact Assessment and Project Appraisal, 31(1), 2-12.

Gmelin, H. and S. Seuring. 2014. Determinants of a sustainable new product development. Journal of Cleaner Production 69: 19. http://dx.doi.org/10.1016/j.jclepro.2014.01.053.

Gutowski, T. G., Sahni, S., Boustani, A., \& Graves, S. C. 2011. Remanufacturing and energy savings. Environmental science \& technology,45(10), 4540-4547.

Hatcher, G.D., Ijomah, W.L. \& Windmill, J.F.C., 2011. Design for remanufacture: a literature review and future research needs. Journal of Cleaner Production, 19(17-18), pp.2004-2014.

IBISWorld. 2015. Countering competition. Revenue grows despite increasing pressure from imports. Report C31.010. Office and Shop Furniture Manufacturing in the UK.

JRC, Revision of the European Ecolabel and Green Public Procurement (GPP) Criteria for Furniture.

Karlsson, R. \& Luttropp, C., 2006. EcoDesign: what's happening? An overview of the subject area of EcoDesign and of the papers in this special issue. Journal of Cleaner Production, 14(15-16), pp.1291-1298.

Koshy, E., Koshy, V., \& Waterman, H. (2010). Action research in healthcare. Sage.

Knight, P. \& Jenkins, J.O., 2009. Adopting and applying eco-design techniques: a practitioners' perspective. Journal of Cleaner Production, 17(5), pp.549-558.

Lee, D., \& Bony, L. J. (2008). Cradle-to-cradle design at Herman Miller: moving toward environmental sustainability. HBS Case, (607-003).

Le Pochat, S., Bertoluci, G., \& Froelich, D. 2007. Integrating ecodesign by conducting changes in SMEs. Journal of Cleaner Production, 15(7), 671-680.

Luttropp, C. \& Lagerstedt, J., 2006. EcoDesign and The Ten Golden Rules: generic advice for merging environmental aspects into product development. Journal of Cleaner Production, 14(15-16), pp.1396-1408.

McShane, T. O., Hirsch, P. D., Trung, T. C., Songorwa, A. N., Kinzig, A., Monteferri, B., ... \& Welch-Devine, M. 2011. Hard choices: making trade-offs between biodiversity conservation and human well-being. Biological Conservation, 144(3), 966-972.

Martens, M.L. and M.M. Carvalho. 2016. Key factors of sustainability in project management context: A survey exploring the project managers' perspective. International Journal of Project Management. http://linkinghub.elsevier.com/retrieve/pii/S0263786316300163.

Moses, J. W., \& Knutsen, T. L. (2007). Ways of knowing. Competing Methodologies in Social and Political Research. Basingstoke \& New York: Palgrave Macmillan. 
Niekamp, S., Bharadwaj, U. R., Sadhukhan, J., \& Chryssanthopoulos, M. K. 2015. A multi-criteria decision support framework for sustainable asset management and challenges in its application. Journal of Industrial and Production Engineering, 32(1), $23-$ 36. http://doi.org/10.1080/21681015.2014.1000401

O’ Connor, F.J. Hawkes, D., 2001. A multi-stakeholder abridged environmentally conscious design approach. The International Journal of Life Cycle Assessment 6(4): 250-250.

O’ Rafferty, S. \& O' Connor, F., 2010. Regional Perspectives on Capacity Building for Ecodesign - Insights from Wales. In J. Sarkis, J. J. Cordeiro, \& D. Vazquez Brust, eds. Facilitating Sustainable Innovation through Collaboration SE - 9. Springer Netherlands, pp. 159-183.

Paulson, F., \& Sundin, E. 2015. Challenges and trends within eco-design. InInternational conference on EcoDesign2015, Tokyo, December 2-4, 2015.

Pigosso, Daniela C A, Rozenfeld, H. \& McAloone, T.C., 2013. Ecodesign maturity model: a management framework to support ecodesign implementation into manufacturing companies. Journal of Cleaner Production, (0).

Pigosso, D. C. A., McAloone, T. C., \& Rozenfeld, H. (2016). Characterization of the state-of-the-art and identification of main trends for Ecodesign Tools and Methods: Classifying three decades of research and implementation.Journal of the Indian Institute of Science, 95(4), 405-428.

Prendeville, S., O'Connor, F., Sherry, J., \& Palmer, L. (2013). Ecodesign Trade-Offs in New Product Development. In LCA Avnir Conference. Lille.

Prendeville, S., 2015. Ecodesign and Material Selection for Eco-Innovation in Office Furniture. PhD thesis.

Ramanujan, D., Bernstein, W. Z., Choi, J.-K., Koho, M., Zhao, F., \& Ramani, K. (2014). Prioritizing Design for Environment Strategies Using a Stochastic Analytic Hierarchy Process. Journal of Mechanical Design, 136(7), 71002. Retrieved from http://dx.doi.org/10.1115/1.4025701

Robson, C., \& McCartan, K. 2016. Real world research. Wiley.

Rossi, M., Germani, M., \& Zamagni, A. 2016. Review of ecodesign methods and tools. Barriers and strategies for an effective implementation in industrial companies. Journal of Cleaner Production. http://doi.org/10.1016/j.jclepro.2016.04.051

Russo, D., Regazzoni, D., \& Montecchi, T. 2011. Eco-design with TRIZ laws of evolution. Procedia Engineering, 9, 311-322. http://doi.org/10.1016/j.proeng.2011.03.121

Russo, D., Rizzi, C., \& Montelisciani, G. 2014. Inventive guidelines for a TRIZ-based eco-design matrix. Journal of Cleaner Production, 76, 95-105. http://doi.org/10.1016/j.jclepro.2014.04.057

Russo, D., Serafini, M., \& Rizzi, C. 2016. Is TRIZ an Ecodesign Method?. In Sustainable Design and Manufacturing 2016 (pp. 525-535). Springer International Publishing.

Sherwin, C. \& Evans, S., 2000. Ecodesign innovation: is "early" always "best"? In International Symposium on Electronics and the Environment. pp. 112-117.

Souza, G. C. 2013. Closed-Loop Supply Chains: A Critical Review, and Future Research*. Decision Sciences, 44(1), 7-38.

Spitzley, D. V, Dietz, B.A. \& Keoleian, G.A., 2006. Life-Cycle Assessment of Office Furniture Products Life-Cycle Assessment of Office Furniture Products. Ann Arbor. Available at: http://css.snre.umich.edu/css_doc/CSS06-11.pdf.

TNO. 2006. Environmental Impacts of Products (EIPRO): Analysis of the life cycle environmental impacts related to the consumption of the EU-25

Tukker, A. (2015). Product services for a resource-efficient and circular economy-a review. Journal of cleaner production, 97, 76-91.

Tyl, B., F. Vallet, N.M.P. Bocken, and M. Real. 2015. The integration of a stakeholder perspective into the front end of ecoinnovation: a practical approach. Journal of Cleaner Production 108: 543-557. http://linkinghub.elsevier.com/retrieve/pii/S0959652615010768. 
UNEP. 2010. Assessing the environmental impacts of consumption and production - Priority Products and Materials.

Van de Ven, A. H. 2007. Engaged scholarship: a guide for organizational and social research: a guide for organizational and social research. OUP Oxford.

Verhulst, E., C. Boks, M. Stranger, and H. Masson. 2007. The Human Side of Ecodesign from the Perspective of Change Management. Science: 107-112. http://dx.doi.org/10.1007/978-1-84628-935-4_19.

Verhulst, E., Boks. C., 2012. Sustainable Design Strategies in Practice and Their Influence on Business Models. Design for Innovative Value Towards a Sustainable Society - Proceedings of EcoDesign 2011 - 7th International Symposium on Environmentally Conscious Design and Inverse Manufacturing: 413-418.

Yin, R.K., 2003.Case Study Research: Design and Methods L. Bickman \& D.J. Rog, eds., Sage Publications

Zhang, F., M. Rio, R. Allais, P. Zwolinski, T.R. Carrillo, L. Roucoules, E. Mercier-Laurent, and N. Buclet. 2013. Toward an systemic navigation framework to integrate sustainable development into the company. Journal of Cleaner Production 54: 199214. http://dx.doi.org/10.1016/j.jclepro.2013.03.054. 


\section{Appendix A - Interview Guides}

\section{Designer Interview Guide}

Date:

Location:

Interviewee:

\section{Project Overview}

- Key project aims

- Design brief

- Project team and key suppliers

- Duration - breakdown of structure of NPD activities

- For some projects, you have set specific ecodesign strategies seat out in the

- brief. Can you describe any ecodesign criteria in the project brief? How were

- these targets decided on?

\section{Design and Development}

- Describe the design process for this project.

- Can you talk me through the key innovations in this product?

- How did these innovations come about?

- What were the key decisions around them?

- What expertise was required to deliver them?

- What were the major design challenges?

- What stage in the design process did the ideas come?

- What were the requirements from the material?

- Who was involved in the decision-making?

\section{Materials \& Manufacturing Processes}

- Could you describe the material selection approach for the product?

- What materials are used in each of the key innovations? Why were these materials used?

- What are the main manufacturing processes for each innovation?

- When in the design process did you decide to use this set of materials?

- Did you introduce any new materials to the portfolio during this NPD?

- How is the material grade decided on? Do variations in grades affect your design?

- What is the impact of specifying material grades on the product design, if any?

- How do you consider recycled content during the design process?

- Were there any materials that you wanted to use but didn't or couldn't for some reason? If so, can you elaborate please?

\section{Additional Comments}

- Do you have any other comments? 


\section{Supplier Interview Guide}

Date:

Location:

Interviewee:

Participant Information Sheet

\section{Business Overview}

- Main Business Activities

- Typical Clients

- Key applications and sectors

- Supply Chain Position

\section{Design and Development}

- You work quite closely with the design team at Orangebox. Can you describe your role during their NPD processes?

- Were you involved in the development of products, A, B, C and D? Could you describe your role in each of these?

- What stages of the process are you involved in?

- What type of information requests do you receive from the design team? Could you elaborate on this?

- Do you tend to give recommendations for specific materials during the NPD process? If YES could you elaborate on this?

- What is the influence of the product design on your manufacturing processes and material choice?

\section{Materials and Processes}

- Please describe your material portfolio and manufacturing processes.

- How do new materials typically come into your portfolio? Can you give an example?

- What are the challenges to increasing recycled content in your products? Can you give some examples?

- Do you tend to specify material grades? If yes, could you elaborate? If no, why not?

- [Specific to Supplier X] Orangebox previously undertook a C2C certification of one of their products. I believe 'you supported them in this process? Could you describe your role in the C2C certification?

\section{Additional Comments}

- Do you have any additional comments? 


\section{Waste Manager Interview Guide}

Date:

Location:

Interviewee:

Participant Information Sheet

\section{Business Overview}

- Main Business Activities

- Typical Clients

- Key applications and sectors of waste material

- Supply Chain Position

\section{Materials and Processes}

- Can you give me an overview of materials being processed at the site?

- Can you give me an overview of sorting, disassembly and separation processes at the site? Can you describe what happens to these types of products when they arrive at the facility?

- What is the relevance of high or low recycled contents on your processes, if any?

- What is the relevance of varying material grades on your processes, if any?

\section{Design and Development}

- What is the influence of the product design on your processes?

- If you could give recommendations to designers when specifying materials what would

- they be?

- In relation to products A, B, C and D? Could you describe the typical processing for

- each of these products?

- In relation to products A, B, C and D? Are there any aspects of the design that are

- particularly problematic for you to manage?

\section{Additional Comments}

- Do you have any additional comments? 
Purpose The aim of the case studies is to examine decision-making during new product development and from this map a set of ecodesign dilemmas

\begin{tabular}{|c|c|}
\hline Objectives & $\begin{array}{l}\text { - Determine general design approach for each case } \\
\text { - Determine ecodesign criteria defined in the brief } \\
\text { - Determine key decisions made to realise a given criteria, or, if } \\
\text { criteria were adapted determine why and how } \\
\text { - Reflect on the outcomes realised in the product through } \\
\text { evaluations of design features }\end{array}$ \\
\hline $\begin{array}{l}\text { Unit of } \\
\text { Analysis }\end{array}$ & $\begin{array}{l}\text { The focus of the cases is on ecodesign decisions made by design } \\
\text { practitioners during processes of new product development }\end{array}$ \\
\hline Structure & $\begin{array}{l}\text { - } \text { Background \& context } \\
\text { - } \text { Motivation and rationale for new product } \\
\text { - } \text { Key project team } \\
\text { - } \text { Ecodesign criteria in brief } \\
\text { - } \text { processes, features) } \\
\text { - Description of material selection decisions } \\
\text { - } \text { Descriptions of key product eco-innovations } \\
\text { Bills of materials analysis and abridged LCA per product }\end{array}$ \\
\hline Interpretation & $\begin{array}{l}\text { - Comparison of ecodesign strategies defined at beginning of each } \\
\text { new product development with features realised in final product } \\
\text { - Comparison of ecodesign strategies applied with those identified in } \\
\text { the literature review } \\
\text { - Reflection on key product eco-innovations with key suppliers and } \\
\text { other stakeholders (material analysts, waste management } \\
\text { providers) } \\
\text { - Comparison of bills of materials and LCA results between cases A, } \\
\text { C, D } \\
\text { - Pattern-matching across and between cases and with the wider } \\
\text { literature }\end{array}$ \\
\hline $\begin{array}{l}\text { Sources of } \\
\text { Information }\end{array}$ & $\begin{array}{l}\text { Primary } \\
\text { - Interviews } \\
\text { - Observations } \\
\text { Secondary } \\
\text { - Product communications } \\
\text { - Project meeting notes (review, managerial, suppliers) } \\
\text { - Internal project reports, e-mails, presentations }\end{array}$ \\
\hline
\end{tabular}




\section{Highlights}

- Ecodesign dilemmas are framed as hierarchies, tensions, contradictions and oversights

- Operational, tactical and strategic actions are needed to manage ecodesign dilemmas

- The business model is critical to contextualise ecodesign decision-making

- Design can drive firms towards business model innovation 